DOI 10.37882/2223-2982.2020.05.32

\title{
ИЗ ОПЫТА РЕАЛИЗАЦИИ СТРУКТУРНО-ФУНКЦИОНАЛЬНОЙ МОДЕЛИ СОВРЕМЕННОЙ ОБРАЗОВАТЕЛЬНОЙ СРЕДЫ ДЛЯ РАЗВИТИЯ ЛИЧНОСТИ УЧАЩИХСЯ С ОСОБЫМИ ОБРАЗОВАТЕЛЬНЫМИ ПОТРЕБНОСТЯМИ В СИСТЕМЕ ОБРАЗОВАНИЯ Г.О. КРАСНОГОРСК
}

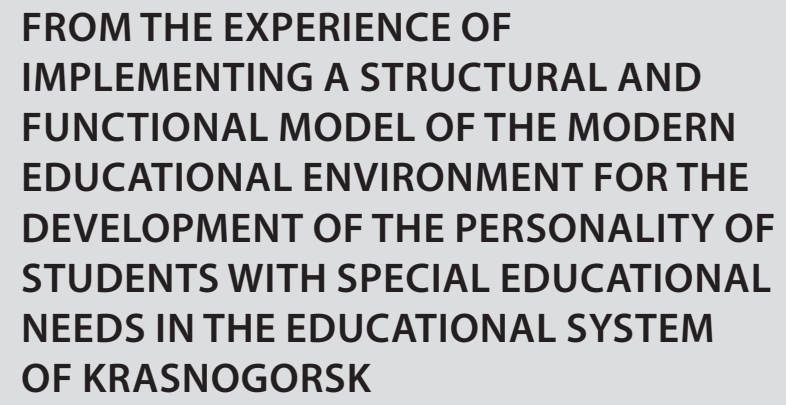

S. Syurin

Summary: This article analyzes the structural-functional model of the modern educational environment for personal development of pupils with special educational needs in the educational system of G.0. Krasnogorsk, the peculiarities of organization of material and technical equipping of educational organizations operating in the mode of network interaction, the performance and efficiency of the model. The main achievements of the implemented model are described: the introduction of the principle of network interaction; the mechanism for successful integration and social and labor adaptation of students with OOP; creation of the AOP catalog; development of effective technologies for variable and differentiated education; creation of a municipal system of continuous professional development and professional retraining of teachers and the formation of a municipal correctional and developmental cluster for students with OOP.

Keywords: special educational needs, limited health opportunities, structural and functional model, network interaction principle, habilitation.
A ктуальность темы данной статьи обусловлена тем, что в ней рассматривается практика реализации структурно-функциональной модели современной образовательной среды, которая создана в системе образования г. о. Красногорск для развития личности учащихся с особыми образовательными потребностями (далее - ООП). Опыт ее применения может быть полезен для муниципальных образований или субъектов России, занимающихся разработкой и реализацией инклюзивной образовательной практики.
Сюрин Сергей Николаевич

Директор, МБОУ «Образовательный центр «Созвездие»»; председатель ТПМПК г.о. Красногорск

Московской области surin2002@mail.ru

Аннотация: В данной статье проанализирована структурно-функциональная модель современной образовательной среды для развития личности учащихся с особыми образовательными потребностями в системе образования г.0. Красногорск, рассмотрены особенности организации материально-технического оснащения образовательной организации, работающей в режиме сетевого взаимодействия, результативность и эффективность функционирования модели. Описаны основные достижения реализуемой модели: внедрение принципа сетевого взаимодействия; механизма успешной интеграции и социально-трудовой адаптации учащихся с 00П; создание каталога А00П; разработка эффективных технологий вариативного и дифференцированного образования; создание муниципальной системы непрерывного повышения квалификации и профессиональной переподготовки педагогических кадров и формирование муниципального коррекционно-развивающего кластера для учащихся с 00П.

Ключевые слова: особые образовательные потребности, ограниченные возможности здоровья, структурно-функциональная модель, принцип сетевого взаимодействия, абилитация. 
представителей Министерства образования Московской области, Министерства образования и науки республики Башкортостан, уполномоченного по правам человека в Московской области и др. В ряде регионов Российской Федерации происходит адаптация модели к условиям ее реализации в регионах (Республика Башкортостан, Ханты-Мансийский автономный округ, г. Петропавловск-Камчатский, Московская область и др.). В республике Башкортостан спроектирован и строится Республиканский центр - аналог МБОУ «Образовательный центр «Созвездие»» г. о. Красногорска.

Целью данной статьи является обобщение и представление опыта функционирования модели в системе образования г.о. Красногорск, обеспечивающей оптимальные психолого-педагогические условия воспитания, обучения, развития и социализации, социально-трудовой адаптации, получения профессии в результате профессионального обучения, дальнейшего трудоустройства и (или) профессионального образования учащихся с ООП, исходя из особенностей типа дизонтогенеза.

Анализ нормативно-правовой базы и психолого-педагогической литературы показывает, что, во-первых, в конце XX в. - начале XXI в. в российском обществе, в общем образовании и инклюзивном образовании получили активное развитие гуманистические идеи. Во-вторых, в стране начался процесс ликвидации закрытых психоневрологических интернатов и психиатрических больниц, в которых содержались дети и подростки с разнообразными психическими отклонениями. В-третьих, в обучение и воспитание, социализацию и реабилитацию учащихся с ООП стало активно вовлекаться их микросоциальное окружение (семья, родственники и т. п.). В-четвертых, на фоне этих процессов произошел переход от сегрегационного подхода, при котором учащиеся с ООП получают образование в автономных (по сути - закрытых) учреждениях и классах, изолированно от социального окружения, что затрудняет их социализацию, к гуманистическому и человекоцентрированному подходу.

При гуманистическом и человекоцентрированном подходе происходят интеграция и инклюзия (от inclusion - включение) учащихся с ООП в сферу общего образования. Интеграция учащихся с ООП подразумевает более «открытую» форму образования, при которой они имеют возможность формирования навыков эффективной коммуникации с нормотипичными сверстниками, активно участвуют в жизни образовательной организации, при этом процесс их обучения адаптирован к ООП. Инклюзивная образовательная практика предполагает постепенный и бережный процесс включения учащегося с ООП в образовательную среду, учитывающую его индивидуальные психические особенности.
Анализ научных источников показывает, что настоящее время в системе образования России реализуется так называемая «традиционная» модель обучения и воспитания детей с ООП, при которой применяются как сегрегационный, так интегративный и инклюзивный подходы. В рамках реализации любого из этих подходов ребенок с ООП получает образование, в той или иной степени адаптируется к условиям взрослой жизни, получает навыки профессионального обучения. Вместе с тем, применение любого из выше обозначенных подходов ограничивается конкретной образовательной организацией, ее ресурсами, традициями, особенностями педагогического и коррекционно-развивающего процесса. Очень часто созданные специальные условия получения образования для учащихся с ООП не учитывают в полной мере принцип преемственности между уровнями общего образования. Репертуар предпрофессиональных навыков учащихся зависит от материально-технического оснащения школы, ассортимент профессий часто не учитывает современное состояние рынка труда конкретного муниципального образования. Многие выпускники с ООП имеют большие трудности с трудоустройством и социальной адаптацией к взрослой жизни.

Разобщенность образовательных организаций г.о. Красногорск в вопросах обучения и воспитания, коррекционно-развивающего сопровождения учащихся с ООП, недостаточный уровень преемственности между организациями общего образования, необходимость развития вариативных и дифференцированных форм комплексного психолого-медико-социального сопровождения сформировали потребность создания инновационной модели современной образовательной среды для развития личности учащихся с ООП. При этом требовалось интегрировать усилия педагогических коллективов в вопросах развития личности учащихся с ООП, создать систему профессионально-трудовой адаптации и профессионального обучения, учитывающей не только индивидуальные особенности «особых» детей, но и рынок труда в муниципалитете.

По мнению Н.В. Софроновой и Р.И. Гороховой, моделирование педагогических систем является одной из важнейших задач современного образования. С каждым годом возрастает значимость проектирования и внедрения инновационных технологий, соответствующих современным идеям отечественной педагогике. Метод моделирования описан в трудах В.П. Давыдова, А.Н. Дахина, О.Х. Рахимова, В.А. Штоффа и др.

Разработанная модель получила название структурно-функциональной. В данном контексте она рассматривается как совокупность закономерных, функционально связанных компонентов, составляющих целостную систему. Компоненты модели раскрывают внутреннюю организацию процесса формирования современной об- 
разовательной среды для полноценного развития учащихся с ООП, обеспечивают взаимодействие между его элементами. Они имеют следующее функциональное назначение:

- целевой компонент выполняет функцию целеполагания;

- содержательный компонент - конструктивно-содержательную функцию;

- процессуальный компонент - процессуальную функцию;

- контрольно-оценочный компонент - функцию контроля и оценки.

Компоненты модели реализуются с опорой на системный, деятельностный и личностно-ориентированный подходы к образованию и развитию личности учащихся с ООП. Все компоненты модели располагаются последовательно, взаимно дополняя друг друга за счет функционального назначения, составляя при этом целостный процесс формирования современной образовательной среды, способствующей развитию личности учащихся с ООП. Каждый компонент получил содержательное наполнение, исходя из функций и специфики исследуемого процесса.

Теоретическую основу для разработки модели составили труды Д.И. Азбукина, П.П. Блонского, Л.С. Выготского, Е.В. Герье, А.Н. Граборова, Л.В. Занкова, В.П. Кащенко, Г.И. Россолимо, Н.В. Чехова по проблемам обучения и воспитания умственно отсталых детей и подростков; исследования И.А. Васильева, Е.Ф. Заморенко, С.С. Преображенского, Ф.А. Рау, Н.А. Рау, Д.В. Фельдберга по проблеме обучения глухих и слабослышащих учащихся; научные работы А. Адлера, А.С. Ганжий, Ю.Д. Жаренцева, Б.И. Коваленко, Н.Б. Коваленко о сопровождении и развитии слепых и слабовидящих.

Разработка компонентов модели осуществлялась с позиций:

- системного подхода (В.Г. Афанасьев, И.В. Блауберг, В.Н. Садовский, Г.Н. Сериков, Э.Г. Юдин и др.);

- деятельностного подхода (Л.С. Выготский, В.В. Давыдов, А.Н. Леонтьев, С.Л. Рубинштейн, Д.Б. Эльконин и др.);

- личностно-ориентированного подхода (Ш.А. Амонашвили, Е.В. Бондаревская, В.В. Сериков, И.С. Якиманская и др.);

- психологические теории развития личности (Л.С. Выготский, А.Н. Леонтьев);

- концепции и теории общего образования (А.Г. Асмолов, А.В. Хуторской, Е.А. Ямбург);

- теории и диалогические концепции отношений (Г.С. Батищев, М.М. Бахтин, М. Бубер).

На основе вышеперечисленных теорий, концепций и подходов формирование модели стало осуществляться специалистами муниципального бюджетного общеобразовательного учреждения «Образовательный центр «Созвездие»» (далее - МБОУ «ОЦ «Созвездие»») для детей с ООП, которое было открыто в г. о. Красногорск 30 декабря 2005 г. В реализуемой модели МБОУ «ОЦ «Созвездие»» занял центральное место, став единым методическим и координационным центром для всех образовательных организация г. о. Красногорск в вопросах реализации технологий комплексного психолого-медико-социального сопровождения и создания современной образовательной среды для развития личности учащихся с ООП. С момента основания МБОУ «ОЦ «Созвездие»» главными задачами данной образовательной организации применительно к рассматриваемой модели являются:

- консолидация усилий педагогических работников детских садов и школ округа в решении вопросов всесторонней помощи детям с ООП;

- раннее выявление у воспитанников и учащихся различных форм дизонтогенеза и оказание им комплексной психолого-медико-социальной помощи;

- оказание методической помощи образовательным организациях в вопросах целенаправленного создания специальных психолого-педагогических условий для воспитания и обучения несовершеннолетних с ООП;

- разработка и реализация адаптированных основных общеобразовательных программ (далее - АООП) для воспитанников и учащихся с ООП;

- повышение уровня профессиональной компетентности педагогических работников системы образования г.о. Красногорск посредством проведения курсов повышения квалификации и профессиональной переподготовки, организации деятельности постоянно действующих семинаров, круглых столов и мастер-классов по диссеминации педагогического опыта в сфере сопровождения учащихся с ООП;

- координация деятельности образовательных организаций в вопросах реализации технологий специального (коррекционного) и инклюзивного образования для детей с ООП.

Как показывает практика, формирование современной образовательной среды для развития личности учащихся с ООП невозможно без комплексного и непрерывного вовлечения в реабилитационный и коррекционно-развивающий процесс педагогического, медицинского, ученического и родительского сообществ, представителей волонтерских объединений, применения технологий междисциплинарной коммуникации и сетевого взаимодействия. Только целенаправленными и совместными усилиями можно сформировать толерантное и позитивно окрашенное отношение к лицам с ООП, способствовать дальнейшему изменению отношения 
общества к детям с инвалидностью и различными типами дизонтогенеза.

Разработанная модель апробировалась на базе школьного и коррекционного отделения МБОУ «ОЦ «Созвездие»», МБОУ СОШ № 3, МБОУ гимназия № 5, МБОУ «Начальная школа-детский сад» для детей с нарушениями зрения, в 24 дошкольных образовательных организациях г. о. Красногорск с 01.09.2006 г. по 31.08.2013 г. В апробации модели приняло участие свыше 6000 воспитанников детских садов и учащихся школ округа. С 31.08.2013г. модель считается внедренной в системе образования г.о. Красногорск в соответствии с приказом начальника управления образования №129 от 02.09.2013г. «Об улучшении работы в сфере сопровождения воспитанников МБДОУ и обучающихся МБОУ, нуждающихся в психолого-педагогическом и медико-социальном сопровождении». Реализация модели позволила создать на территории округа единое пространство для обучающихся с ООП от рождения до периода взрослости, охватывающего возрастной диапазон от 0 до 23 лет. При этом происходит непрерывный процесс развития каждого ребенка в ходе организации взрослыми совместной общественно-полезной деятельности (учебной, внеурочной, игровой, экспериментальной и др.), диагностируются и учитываются индивидуальные особенности, реализуются способности каждого обучающегося в общем образовании, потребности учащихся в получении профессии рабочего или дальнейшего профессионального образования.

Учитывая, что МБОУ «ОЦ «Созвездие»» является координирующим органом реализуемой модели, в нем осуществляется анализ существующей сети инклюзивных дошкольных групп и классов в школах, осуществляется работа по созданию специальных психолого-педагогических условий для получения образования воспитанниками и учащимися с ООП, расширяется репертуар вариативных и дифференцированных форм их воспитания и обучения. За период с 30.12.2005 г. по 01.01.2020 г. при участии специалистов МБОУ «ОЦ «Созвездие»»:

- оказана амбулаторная психолого-медико-социальная помощь свыше 45000 несовершеннолетних с ООП;

- создано и функционирует свыше 11700 мест в образовательных организациях округа для воспитанников и обучающихся с ООП;

- реализуется свыше 20 вариантов АООП;

- в школьном отделении МБОУ «ОЦ «Созвездие»» обучается по АООП для детей с различными типами дизонтогенеза, нарушениями интеллекта разной степени тяжести свыше 430 чел., В т. ч., более 120 чел. с орфанными заболеваниями, тяжелыми и множественными нарушениями развития.

Важно отметить, что реализация модели предпо- лагает функционирование образовательных организаций общего образования в режиме сетевого взаимодействия, которое носит интегральный характер и распространяется как на уровень дошкольного, так и школьного образования, от раннего развития детей до профессионального обучения старшеклассников и получения ими профессиональных компетенций.

В ходе работы над созданием и апробацией модели нами были определены основные уровни развития детей (обучающихся):

- раннее развитие ребенка (от 0 до 3 лет);

- дошкольное образование и развитие (от 3 до 7 лет);

- начальное общее образование и развитие (от 7 до 11 лет);

- основное общее образование и развитие (от 11 до 16 лет), включающий социально-трудовую адаптацию (с 13 до 16 лет);

- профессиональное обучение и развитие (с 16 до 18 лет);

- самостоятельная трудовая деятельность человека с ООП (с 18 до 23 лет).

Реализация модели на каждом из выше перечисленных уровней развития детей (обучающихся) с ООП предполагает применение специалистами Центра следующих видов сопровождения:

- логопедическая диагностика и коррекция нарушений первичных и вторичных нарушений всех компонентов речи у воспитанников и обучающихся с учетом выявленных у них индивидуальных психофизических особенностей дизонтогенеза;

- психолого-педагогическая диагностика и коррекция интеллектуально-мнестической и эмоционально-волевой сфер личности, коммуникативных навыков у обучающихся;

- дефектологическая диагностика и коррекция нарушений познавательных процессов, формирование первичных учебных навыков и универсальных учебных действий, восполнение пробелов знаний у обучающихся;

- педагогическое сопровождение, включающее создание и реализацию технологий педагогического мониторинга, условий получения образования, АООП, специальных индивидуальных программ развития, организацию досуговой и внеурочной деятельности, проведение олимпиад, конкурсов и фестивалей творческих достижений;

- медико-реабилитационное сопровождение, включающее первичное углубленное медицинское обследование обучающихся врачами-специалистами (психиатр, невролог, психотерапевт, офтальмолог, оториноларинголог, реабилито- 
лог, стоматолог), медицинскую реабилитацию с использованием медикаментозного лечения, физиотерапии, медицинского массажа, нейрореабилитации и миостимуляции, технологий бальнеолечения, адаптивной физической реабилитации, гидротерапии, иппотерапии и механотерапии, локомоторной и компьютерной терапии с применением технологий биологической обратной связи (далее - БОС) и др.

Вышеуказанные виды сопровождения в модели реализуются в форме междисциплинарного взаимодействия педагогических коллективов образовательных организаций, специалистов по комплексному психолого-медико-социальному сопровождению и медицинских специалистов. Модель реализуется в системе образования г.о. Красногорск, которая включает 53 дошкольные образовательные организации и 34 общеобразовательные образовательные организации. При этом МБОУ «ОЦ «Созвездие»» выполняет функции единого методического центра для образовательных организаций округа в вопросах реализации технологий инклюзивного и специального образования.

Посредством того, что на базе МБОУ «ОЦ «Созвездие» сформирована и функционирует территориальная психолого-медико-педагогическая комиссия, а также амбулаторное отделение для оказания комплексной психолого-медико-социальной помощи воспитанникам и обучающимся с ООП, систематически осуществляется работа по эффективной маршрутизации несовершеннолетних, нуждающихся в создании специальных условий для развития их личности. Поэтому специалисты МБОУ «ОЦ «Созвездие»» могут своевременно привлекать для комплексного сопровождения обучающихся с ООП ресурсы любой образовательной организации округа. Все эти организации при работе с учащимися с ООП работают в режиме сетевого взаимодействия.

В ходе реализации модели специалистами управления образования городского округа и МБОУ «ОЦ «Созвездие»» особое внимание уделяется совершенствованию материально-технической базы всех образовательных организаций городского округа, включая МБОУ «ОЦ «Созвездие» как единого координирующего центра. С этой целью:

- проводится анализ выполнения санитарно-гигиенических нормативов при организации образовательного процесса с учетом потребностей детей с ООП;

- разрабатываются маршруты беспрепятственного доступа обучающихся с ООП к образовательной инфраструктуре городского округа;

- создаются общие и индивидуальные санитарно-бытовые условия (гардеробные, столовая, туалетные комнаты, оборудование учебных ка- бинетов, персональных учебных мест и др.), учитывающие особенности обучающихся с ОВ3;

- адаптируются системы противопожарной и электробезопасности, антитеррористической защищенности с учетом индивидуальных особенностей учащихся с ООП.

Практика показала, что при реализации модели в структуре материально-технического обеспечения учебной деятельности учащихся с ООП должны обязательно учитываться следующие особенности:

- организация учебного пространства;

- организация временного режима;

- организация специализированных рабочих мест;

- применение технических средств обучения (далее - ТСО) и ассистирующих технологий;

- использование индивидуальных ТСО для удовлетворения специальных образовательных потребностей.

Оснащение образовательной организации, участвующей в реализации модели, предусматривает:

- оснащение учебных кабинетов специальной мебелью, в том числе, столы с регулируемой высотой и углом наклона столешницы, стулья, регулируемые по высоте;

- психодиагностические комплекты для углубленной психолого-педагогической, дефектологической и логопедической диагностики актуального уровня развития познавательной, эмоционально-волевой и коммуникативной сфер личности ребёнка с ООП;

- интерактивные коррекционные средства: интерактивные доски, проекторы, коррекционные проекционные столы и полы, интерактивная песочница;

- оснащение кабинетов коррекционно-развивающего обучения аппаратно-программными комплексами, основанными на технологиях БОС;

- использование кабинетов логотерапевтической коррекции;

- применение логопедических, психологических программ для коррекционно-реабилитационной работы с детьми с ООП;

- специализированное оборудование комнат сенсорного развития и Монтессори педагогики;

- разработка и внедрение учебно-методических пособий педагога-психолога, учителя-логопеда для работы с детьми с нарушениями речи, нарушениями познавательных процессов и эмоционально-волевой сферы;

- специализированный транспорт для перевозки детей-инвалидов, относящихся к категории маломобильных групп населения (далее - МГН).

Внедрение в систему общего образования г.о. Крас- 
ногорск модели инициировало процесс проектирования и строительства нового многофункционального здания МБОУ «ОЦ «Созвездие»». С 01.09.2019 г. специалисты Центра стали осуществлять свою деятельность В новом здании, в полной мере реализуя принципы многопрофильности и комплексности помощи, вариативности и дифференцированности образования несовершеннолетних с ООП. При этом в пределах одного здания сформировано 5 основных структурных подразделений, содержание деятельности которых показано в таблице 1.
Анализ эффективности функционирования модели осуществлялся в период с 01.01.2014 г. по 01.01.2020 г. с помощью следующих методов:

- анкетирование педагогических работников, специалистов по коррекционно-развивающему сопровождению, медицинских специалистов, родительской общественности;

- мониторинг охвата учащихся с ООП различными видами помощи;

- мониторинг профессиональной компетентности педагогов и специалистов.

Структурные подразделения МБОУ «ОЦ «Созвездие»» и содержание их деятельности

\section{Медико-реабилитационное отделение}

- оказание комплексной медико-реабилитационной помощи детям с 00П, детям-инвалидам, в т.ч. с тяжелыми и множественные нарушениями развития, орфанными заболеваниями и пр. (физиолечение, стоматологическое лечение, бальнеолечение, спелео- и климатотерапия, ароматерапия, ЛФК, механотерапия, роботехническая коррекция двигательной активности у детей с НОДА и последствиями травм ЦНС; коррекция нарушений зрения, дыхания, осанки, амблиопии, миопии, дальнозоркости с использованием БОС технологий и компьютерного коррекционноразвивающего сопровождения; медицинское наблюдение с уточнением структуры и типа дизонтогенеза).

Охват: не менее 1200-1500 детей-инвалидов и лиц с 00П в год

\section{Коррекционное отделение}

- оказание комплексной психолого-медико-социальной помощи (педагоги-психологи, учителя-логопеды, учителя-дефектологи, социальные педагоги, врач-психиатр, невролог, офтальмолог, оториноларинголог, педиатр и др.) детям с 00П, детям-инвалидам, несовершеннолетним с деструктивными формами поведения, В т.ч. аутодеструкцией, трудностями в обучении, имеющим тяжелые и множественные нарушения развития и проживающим на территории г.о. Красногорск (для жителей Московской области организована консультативная помощь);

- психолого-медико-педагогическое освидетельствование в рамках деятельности ТПМПК г.о. Красногорск;

- служба ранней помощи в системе образования г.о. Красногорск;

- консультирование педагогической и родительской общественности в вопросах реализации инклюзивной модели образования, профилактической деятельности в ОУ, методическое сопровождение деятельности педагогов-психологов, учителей-логопедов и учителей-дефектологов МБОУ и МБДОУ г.о. Красногорск, взаимодействие с ПМПк и социально-психологическими службами ОУ, организация деятельности, выполнение функций муниципального оператора по реализации ИПРА в системе образования г.о. Красногорск;

- организация деятельности Центра сопровождения замещающих семей г.о. Красногорск.

Охват: Амбулаторное сопровождение ли от 0 до 23 лет, проживающих на территории г.о. Красногорск и в др. мун. образований М0 (консультативно), 120 140 посещений в день (5500-6000 чел. в год)

\section{Отделение дифференцированного и индивидуализированного обучения детей с ТМНР и службой раннего развития}

- обучение по специальным АООП, индивидуальным учебным планам, а также СИПРам детей-инвалидов и лиц с 00П с учетом их индивидуальных психофизиологических особенностей (вариант 6.4., 8.4. ФГОС НОО с ОВЗ и вариант 2 ФГОС 0 с У/0);

- постепенная интеграция в систему образования детей-инвалидов, в т.ч. с ТМНР, находящихся в условиях семейного, надомного и дистанционного обучения (формирование и функционирование специализированных классов для детей с ТМНР).

Охват: не менее 100 детей-инвалидов с ТМНР, обучающихся в режиме дифференцированного и индивидуализированного обучения, в т.ч. не менее 4 специализированных классов для детей с ТМНР (ежегодная интеграция до 30\% детей-инвалидов, обучающихся индивидуально)

\section{Школьное отделение}

— обучение по АООП (вариант 2.1.; 2.2.; 2.3.; 4.1.; 4.2.; 4.3.; 5.1.; 6.1.; 6.2.; 6.3.; 7.1.; 7.2.; 8.1.; 8.2.; 8.3. ФГОС НОО с ОВ3);

- обучение по АООП (вариант 1 и 2 ФГОС 0 с У/0).

Охват: не менее 30 классов обучающихся по АООП (кол-во обучающихся в классе до 15чел.) - 480чел. с 00П и детей-инвалидов в год

\section{Отделение профессионально-трудовой адаптации и профессионального обучения лиц с 00П}

— - подготовка детей-инвалидов и лиц с 00П к самостоятельной трудовой деятельности, формирование ключевых профессиональных компетенций по рабочим профессиям;

- профессиональная подготовка лиц с 00П, детей-инвалидов и обучающихся, имеющих трудности в обучении по рабочим профессиям (слесарное и столярное дело, швейное дело, поварское дело, автодело, парикмахерское искусство, мастер маникюра и педикюра, гончарное дело, картонажно-переплетное дело, работник клининговой службы, озеленитель)

Охват: не менее 6 групп обучающихся по профессиям, которые выбраны лицами с 00П и детьми-инвалидами для получения квалификационного разряда (15чел. в группе) 
Для оценки эффективности функционирования модели были разработаны критерии и показатели. Результаты эффективности модели представлены в таблице 2.

Результаты анализа сравнительной динамики оценки эффективности модели с 2014 г. до 2020 г. показаны в таблице 3.

Анализ данных эффективности функционирования модели показывает, что, несмотря на ежегодное увеличе-

Таблица 2

Критерии и показатели оценки эффективности модели в период с 2014 г. до 2020 г.

\begin{tabular}{|c|c|c|c|c|c|c|c|c|c|c|}
\hline № & Критерий & Показатель & $\begin{array}{l}\text { Ед. } \\
\text { изм. }\end{array}$ & 2014 & 2015 & 2016 & 2017 & 2018 & 2019 & 2020 \\
\hline 1 & $\begin{array}{c}\text { Доступность специали-зиро- } \\
\text { ванной, культурно-досуговой } \\
\text { и абилита-ционной помощи } \\
\text { учащимся с 00П }\end{array}$ & $\begin{array}{c}\text { Кол-во учащихся с 00П, охва- } \\
\text { ченных специализи-рованной, } \\
\text { культурно-досуговой и абили- } \\
\text { тационной помощью (\%) }\end{array}$ & $\%$ & 29,1 & 30,3 & 30,8 & 36,7 & 51,2 & 54,7 & 60,7 \\
\hline 2 & $\begin{array}{l}\text { Развитие познава-тельной, } \\
\text { творческой и социальной ак- } \\
\text { тивности обучающихся с 00П }\end{array}$ & $\begin{array}{c}\text { Дети с 00П, активно про- } \\
\text { являющие себя в процессе } \\
\text { образовательной творческой } \\
\text { деятельности } \\
\text { (положительная динамика) }\end{array}$ & $\%$ & 39,1 & 40,4 & 40,8 & 42,9 & 54,5 & 57,7 & 61,4 \\
\hline 3 & $\begin{array}{c}\text { Метапред-метные, предмет- } \\
\text { ные и личностные результаты } \\
\text { учащихся с 00П }\end{array}$ & $\begin{array}{c}\text { Дети с 00П, успешно осва- } \\
\text { ивающие АООП, имеющие } \\
\text { предметные и личностные } \\
\text { результаты }\end{array}$ & $\%$ & 29,3 & 30,3 & 32,7 & 38,6 & 43,5 & 47,7 & 49,4 \\
\hline 4 & & $\begin{array}{c}\text { Педагоги, прошедшие по- } \\
\text { вышение квалификации и } \\
\text { профессиональную переподго- } \\
\text { товку в сфере сопровождения } \\
\text { обучающихся с 00П }\end{array}$ & $\%$ & 18,1 & 22,7 & 29,9 & 43,5 & 69,4 & 75,8 & 80,9 \\
\hline 5 & $\begin{array}{l}\text { Компетентность } \\
\text { педагогов }\end{array}$ & $\begin{array}{c}\text { Педагоги, принимающие } \\
\text { участие в работе с учащимися с } \\
\text { 00П, диссеминации педагоги- } \\
\text { ческого опыта }\end{array}$ & $\%$ & 15,1 & 22,4 & 29,7 & 31,4 & 49,2 & 61,9 & 72,1 \\
\hline 6 & & $\begin{array}{l}\text { Членство в Ассоциации специ- } \\
\text { алистов по работе с детьми с } \\
\text { ОВЗ Московской области }\end{array}$ & $\%$ & 8,2 & 23,5 & 25,6 & 29,9 & 47,5 & 61,7 & 71,2 \\
\hline 7 & $\begin{array}{c}\text { Интерак-тивные и медийные } \\
\text { образова-тельные ресурсы в } \\
\text { урочной и внеурочной дея- } \\
\text { тельности с учащимися с 00П }\end{array}$ & $\begin{array}{c}\text { Педагогические работники, } \\
\text { использующие интерактивные } \\
\text { и медийные образовательные } \\
\text { ресурсы }\end{array}$ & $\%$ & 22,7 & 29,9 & 37,2 & 47.8 & 69,5 & 74,3 & 81,6 \\
\hline 8 & $\begin{array}{c}\text { Дети-инвалиды с ТМНР, } \\
\text { принимающие участие в } \\
\text { муниципальных и региональ- } \\
\text { ных творческих конкурсах для } \\
\text { детей с 00П }\end{array}$ & $\begin{array}{c}\text { Обучающихся, ставших } \\
\text { победителями и призерами } \\
\text { конкурсов, соревнований } \\
\text { муниципального и региональ- } \\
\text { ного уровня }\end{array}$ & $\%$ & 7,1 & 7,9 & 9,3 & 8,8 & 15,7 & 21,1 & 24,3 \\
\hline 9 & Обучающиеся с 00П & $\begin{array}{c}\text { Обучающиеся с О0П вовлечен- } \\
\text { ные в системный коррекцион- } \\
\text { но-развивающий и учебно- } \\
\text { воспитательный процесс }\end{array}$ & $A 6 c$ & 4974 & 5709 & 6914 & 7995 & 9237 & 10984 & 11773 \\
\hline
\end{tabular}


Сравнительная динамика оценки эффективности (за 2014 - 2020 гг.)

\begin{tabular}{|c|c|c|c|c|}
\hline Критерий & Ед. изм. & 2014 & 2020 & Динамика \\
\hline Критерий/показатель 1 & $\%$ & 29,1 & 60,7 & $\mathbf{+ 3 1 , 6 \%}$ \\
\hline Критерий/показатель 2 & $\%$ & 39,1 & 61,4 & $+\mathbf{2 2 , 3 \%}$ \\
\hline Критерий/показатель 3 & $\%$ & 29,3 & 49,4 & $+\mathbf{+ 1 0 , 1 \%}$ \\
\hline Критерий/показатель 4 & $\%$ & 18,1 & 80,9 & $+\mathbf{+ 6 2 , 8 \%}$ \\
\hline Критерий/показатель5 & $\%$ & 15,1 & 72,1 & $+\mathbf{+ 5 7 , 0 \%}$ \\
\hline Критерий/показатель 6 & $\%$ & 8,2 & 71,2 & $+\mathbf{6 3 , 0 \%}$ \\
\hline Критерий/показатель 7 & $\%$ & 22,7 & 81,6 & $\mathbf{+ 5 8 , 9 \%}$ \\
\hline Критерий/показатель 8 & $\%$ & 7,1 & 24,3 & $\mathbf{+ 1 7 , 2 \%}$ \\
\hline Усредненное значение 1-8 & $\%$ & $\mathbf{2 1 , 0 9 \%}$ & $\mathbf{6 2 , 7} \%$ & $\mathbf{+ 4 1 , 6 1 \%}$ \\
\hline Критерий/показатель 9 & Абс. & 4974 & 11773 & $\mathbf{+ 6 7 9 9} \mathbf{4 е л . ~ ( 2 3 6 \% ) ~}$ \\
\hline
\end{tabular}

ние контингента воспитанников и учащихся с ООП в системе образования городского округа (за анализируемый период рост составляет 236\%), отмечается выраженная положительная динамика по достижению целевых показателей доступности комплексной психолого-медико-социальной помощи детям с различными типами дизонтогенеза. За этот период возросло количество учащихся с ООП, охваченных специализированной, культурно-досуговой и абилитационной помощью $(+31,6 \%) ;$ количество учащихся с ООП, активно проявляющих себя в процессе образовательной творческой деятельности (+22,3\%). По показателю «Дети с ООП, успешно осваивающие АООП, имеющие предметные и личностные результаты» также отмечается положительная динамика (+10,1\%).

Интегральная оценка по критерию «Компетентность педагогов», который включает такие показатели, как прохождение педагогами курсов повышения квалификации и профессиональной переподготовки, участие в диссеминации педагогического опыта и членство в профессиональной ассоциации для специалистов по работе с детьми с ОВ3, уверенно свидетельствует о росте профессионального мастерства педагогов в вопросах комплексного психолого-медико-социального сопровождения обучающихся с различными типами дизонтогенеза (56,4\%). По показателю «Интерактивные и медийные образовательные ресурсы в урочной и внеурочной деятельности с учащимися с ООП» отмечается выраженный рост числа педагогических работников, использующих такие образовательные ресурсы при обучении детей с ООП (+58,9\%). Рост показателя «Дети-инвалиды с ТМНР, принимающие участие в муниципальных и региональных творческих конкурсах для детей с ООП» на 17,2\% свидетельствует о развитии в образовании г. о. Красногорск эффективной системы досуговой и внеурочной занятости для детей с ООП.
Сравнительная интегральная оценка по показателям 1-8 отражает устойчивую положительную динамику: средняя степень достижения по анализируемым параметрам в 2014 г. составила 21,09\%, в 2020 г. - 62,7\%, прирост + 41,61\%. Параметр 9 «Обучающиеся с ООП» показывает прирост в 236\%, что свидетельствует об активном развитии системы инклюзивного образования в г. о. Красногорск и о вовлечении в системный коррекционно-развивающий и учебно-воспитательный процесс обучающихся с ООП.

Таким образом, разработанная специалистами МБОУ «ОЦ «Созвездие»» и реализованная во всех образовательных организациях городского округа модель доказала свою эффективность. Она позволила:

- обосновать и принцип сетевого взаимодействия образовательных организаций общего образования в вопросах воспитания, обучения, социализации и интеграции детей с ООП в системе образования г.о. Красногорск. При этом МБОУ «ОЦ «Созвездие»» стал единым координирующим и методическим центром, который обеспечивает эффективную маршрутизацию детей с ООП и оказывает комплексную многопрофильную помощь всем учащимся с различными типами дизонтогенеза;

- применить механизм успешной интеграции и социально-трудовой адаптации учащихся с ООП в жизнь общества. При этом выбор профессии учащимся с ООП осуществляется с учетом сетевого взаимодействия с работодателями округа и профориентационной работы;

- создать каталог АООП для применения в практической педагогической деятельности для обучающихся с ООП;

- разработать эффективные технологии вариа- 
тивного и дифференцированного образования детей с ООП, которые успешно реализуются в системе образования г. о. Красногорск;

- создать муниципальную систему непрерывного повышения квалификации и профессиональной переподготовки педагогических кадров по актуальным проблемам воспитания, обучения и социализации обучающихся с ООП на базе МБОУ «ОЦ «Созвездие»»;

- сформировать муниципальный коррекционно-развивающий кластер для учащихся с ООП, интегрально охватывающий уровни раннего развития, дошкольного, школьного и профессионального обучения.

Положительный опыт реализации модели позволяет осуществлять перспективное планирование де- ятельности специалистов МБОУ «ОЦ «Созвездие»» по дальнейшему развитию комплексного психолого-медико-социального сопровождения детей, нуждающихся в психолого-педагогической и медико-социальной помощи. В краткосрочной перспективе планируется: открыть отделение стационарной медико-реабилитационной помощи детям с ООП, ТМНР и несовершеннолетним из зон боевых конфликтов (Сирия, Донецкая и Луганская Народные Республики и др.); сформировать Центр «второго мнения» для оказания экспертной, консультативной и медико-психологической помощи педагогам образовательных организаций и родительской общественности Московской области; инициировать создание регионального ресурсного консультативного центра по оказанию комплексной помощи детям с ООП.

\section{ЛИТЕРАТУРА}

1. Бешенков, С.А. Моделирование и формализация: метод. пособие / С.А. Бешенков. - М.: БИНОМ. Лаборатория знаний, 2002. - 336 с.

2. Дахин, А.Н. Педагогическое моделирование: монография/А.Н. Дахин. - Новосибирск: Изд-во НИПКиПР0, 2005. - 230 с.

3. К Каталог психолого-педагогических программ и технологий в образовательной среде. - М.: Общественная организация «Федерация психологов образования России», 2018. 358с.

4. Лодатко, Е.А. Моделирование педагогических систем и процессов: монография/ Е.А. Лодатко. — Славянск : СГПу, 2010. — 148 с.

5. Монахов, В.М. Педагогическое проектирование - современный инструментарий дидактических исследований/В.М. Монахов//Школьные технологии. 2001. - №5. - C. $75-89$.

6. Психолого-педагогические программы и технологии в образовательной среде: каталог - 2019. / Коллективная монография. Под ред. В.В. Рубцова, Ю.М. Забродина, И.В. Дубровиной, Е.С. Романовой. - М.: ФГБОУ ВО МГППУ, 2019. - 297 с.

7. Рачковская, Н.А. Сюрин, С.Н. Новиков, Р.А. Тумаева, О.В. Социально-педагогическая профилактика деструктивного поведения несовершеннолетних (учебно-методическое пособие для социальных педагогов, работников социальной сферы, занимающихся вопросами социально-педагогической профилактики). - М.: 000 «Авиакнига», 2015. - 192с.

8. Софронова, Н.В. Горохова, Р.И. Моделирование педагогических систем: Монография. - Чебоксары: Чувашский гос.пед.ун-т, 2011. - 174 с.

9. Технологии логопедической и дефектологической диагностики детей разных возрастных групп в условиях ППМС центра (учебно-методическое пособие для учителей-логопедов и учителей-дефектологов ППМС центров) / Под общ. ред. С.Н. Сюрина. - Красногорск, 2014. - 148 с.

10. Технология психолого-педагогической диагностики детей и подростков от 3 до 18 лет в условиях специализированного психологического центра (учебно-методическое пособие для педагогов-психологов общеобразовательных организаций и ППМС центров) / Под общ. ред. С. Н. Сюрина. - Красногорск, 2014. -138 c

11. Ясвин, В.А. Образовательная среда: от моделирования к проектированию/В.А. Ясвин. — 2-е изд., испр. и доп. — Москва: Смысл, 2001. — 366

12. Информационная система сопровождения деятельности федеральных инновационных площадок: http://fip.expert/project/1647/show

13. Сайт МБОУ «Образовательный центр «Созвездие»»: http://center-psi.ru/uslugi/kompleksnoe-psihologo-mediko-pedagogicheskoe-obsledovanie 